\title{
ARAH BARU TEOLOG WANITA MUSLIM
}

\author{
Ainun Sakinah $^{1}$, Yodi Fitradi Potabuga ${ }^{2}$ \\ Pascasarjana UIN Sunan Kalijaga Yogyakarta ${ }^{1,2}$ \\ ainunsakinah78@gmail.com
}

\begin{abstract}
Abstrak: Tulisan ini membahas tentang tokoh-tokoh teolog wanita dalam konteks wanita muslim dalam melihat penafsiran-penafsiran terhadap sumber utama Islam yakni Al-Qur'an, Hadis, dan hukum syari'at islam. Metode Hermeneutik menjadi metode yang digunakan oleh para teolog muslim wanita dengan melakukan gerakan pembaruan terhadap tafsiran Al-Qur'an. Artikel ini menggunakan jenis penelitian riset kepustakaan atau library research, metode penelitian kepustakaan atau perpustakaan, dengan menggunakan sumber data primer berupa buku Muslima Theology: The Voice of Muslim Women Theologians. Hasil dari penelitian ini menunjukkan terdapat kelemahan dalam kajian teolog muslim wanita. Hal ini ditunjukkan dari rekonstruksi yang dibangun didominasi pada letupan-letupan kesetaraan gender akan tetapi belum menyentuh pada aspek teologi secara murni. Hal ini juga menjadikan kedudukan teologi muslim wanita masih dalam perdebatan, karena karya yang dihasilkan oleh para muslim wanita ini masih jauh dari kata jelas dan kokoh.
\end{abstract}

Kata Kunci: Teologi, Teolog Muslim Wanita

Agama Islam sama sekali tidak menempatkan perempuan pada posisi yang lebih rendah dibandingkan dengan laki-laki, baik dari segi substansi penciptaannya, tugas dan fungsinya, hak dan kewajibannya, maupun dalam rangka meraih prestasi puncak yang diidam-idamkannya. Islam, melalui kedua sumbernya Al-Quran dan Sunnah, menetapkan posisi dan kedudukan perempuan setara dan seimbang dengan posisi dan kedudukan laki-laki. Tantangan terbesar yang dihadapi kaum perempuan adalah legitimasi teologis terhadap kondisi ketidakadilan yang mereka rasakan, sehingga apa yang mereka lakukan dianggap bertentangan dengan ajaran agama.

Salah satu faktor penyebab terpuruknya posisi perempuan dalam masyarakat muslim adalah penafsiran agama, maka solusi yang ditawarkan pun harus dimulai dengan merevisi penafsiran atau rekontruksi pemikiran. Umat Islam hampir sepakat bahwa ijtihad dalam arti pembaharuan, penafsiran, dan 
pemahaman terhadap Islam adalah suatu kebutuhan dasar. Kebutuhan itu dirasakan bukan hanya setelah Rasulullah tiada, malah ketika masih hidup.

Sudah jelas bahwa secara histori dan doktrin, tidak ada penghalang untuk wanita berkomentar dan menafsirkan teks-teks suci Islam, setelah generasi pertama muslim, wanita pada awalnya berfungsi hanya sebagai penyebar agama dari pada sebagai penafsir agama. Teologi sebagai salah satu produk pemikiran, sesungguhnya merupakan sebuah penafsiran. Teologi dalam tulisan ini dimaknai sebagai bentuk pemahaman dan penafsiran dari Al-Quran. Ketika berbicara penafsiran, maka bangunan teologi yang ada bisa berkeadilan gender bisa juga sebaliknya (bias gender). Pemikiran keagamaan seseorang tidak mustahil dipengaruhi oleh beragam tradisi dan kultur, ideologi, maupun pandangan-pandangan lain.

Pemaknaan dan penafsiran terhadap Al-Quran dapat menjadi sarana ideologis untuk mempertahankan kepentingan dan kekuasaan. Karena itulah, penafsiran-penafsiran itu harus didekonstruksi, yaitu dengan membiarkan AlQuran menguraikan sendiri maknanya tanpa campur tangan kultur yang menghegemoni masyarakat. Al-Quran harus diperlakukan sebagai sebuah teks yang netral dan interpretable terhadap berbagai pemaknaan dan pembacaan.

Diskusi-diskusi yang hidup dan kritis saat ini tentang penafsiran agama dan peran Islam dalam semua bidang kehidupan telah memicu pembaharuan dalam teologi spekulatif di kalangan muslim yang membahas semua bidang keterlibatan etis, interpretatif, dan konstruktif dengan ajaran agama. Ketika wanita muslim kontemporer terlibat dalam penafsiran dan teologi kitab suci, mereka membuka jalan baru di sejumlah wilayah, tidak hanya sebagai wanita, tetapi juga sebagai penafsir tradisi keagamaan dalam konteks tantangan kontemporer yang signifikan. Sumber-sumber mereka tidak bisa dibatasi oleh teologi pra-modern 'ilm al-kalam dan 'aqida, yang mana cenderung menjadi pengajaran dalam argumentasi dan untuk mengatasi halhal yang tidak lagi menarik atau relevan oleh kebanyakan muslim. Oleh karena itu, tulisan-tulisan dari kelompok baru teologi wanita muslim mengambil serangkaian inisiatif yang mendukung pembangunan mereka. Dalam tulisan ini 
akan lebih dispesifikan pada para teolog wanita seperti Asma Barla dan Amina Wadud, sehingga inti dari pembahasan tulisan ini adalah bagaimana gerakan yang dibentuk oleh Asma Barlas dan Amina Wadud dalam mendorong wanita keluar dari pengucilan-pengucilan yang sudah ada terhadap wanita.

\section{METODE}

Penelitian merupakan suatu metode studi yang dilakukan individu dengan melakukan proses penyelidikan sesempurna mungkin akan suatu tema atau masalah sehingga diperoleh solusi atau pemecehan masalah yang tepat. Metode penelitian yang digunakan dalam artikeli ini adalah metode penelitian dengan jenis riset kepustakaan atau library research, metode penelitian kepustakaan atau perpustakaan dinilai sebagai motode penelitian yang otonom dengan menggunakan sistem klasifikasi koleksi perpustakaan. Manfaaat riset kepustakaan untuk memperoleh data penelitian dengan memanfaatkan koleksi perpustakaan dan tanpa memerlukan riset lapangan.

Sumber data dalam arikel ini adalah buku Muslima Theology: The Voice of Muslim Women Theologians yang ditulis oleh Ednan Aslan, Marcia Hermansen, dan Elif Medeni. Buku tersebut menjadi sumber data primer dalam artikel ini, sehingga artikel ini membutuhkan sumber data sekunder sebagai sumber data pendukung. Adapun sumber data sekunder dalam artikel ini adalah artikel yang relevan dengan pembahasan artikel ini. Secara lebih spesifik sumber data sekunder ini berupa artikel yang memiliki tema teologi wanita, teologi Islam, dan buku yang menjelaskan para tokoh yang terdapat dalam artikel ini. Selain jenis penelitian dan sumber data, data dalam artikel ini dikumpulkan dengan menggunakan teknik dokumentasi.

\section{PEMBAHASAN}

\section{Konsep Dasar Teologi Islam}

Dalam banyak agama, dikenal konsep bagaimana manusia beragama itu menyusun konsep ketuhanan yang disebut theo-logi. Theo adalah Tuhan, dalam yunani kuno erat kaitannya dengan zeus (Tuhan petir). Logos artinya argumen, 
dalam tradisi latin merujuk pada pengetahuan. Maka teologi adalah ilmu tentang ketuhanan. William Resee menjelaskan bahwa teologi adalah disiplin ilmu yang membahas serta berbicacra mengenai kebenaran wahyu serta independensi filsafat dan ilmu pengetahuan. Teologi sendiri bersifat transendens yang artinya memiliki hubungan atau keterkaitan dengan keyakinan dan keyakinan itu sendiri terhubung langsug dengan konsep ketuhanan.

Dalam teologi banyak hal yang nampak sulit dipertemukan dengan kesejarahan, walaupun dalam kenyataannya teologi itu sendiri berada dalam sejarah manusia. Teologi lahir dalam konteks sejarah manusia, dipahami oleh manusia, dan juga dikembangkan oleh manusia. Maka berbicara teologi meskipun itu berbicara tentang Tuhan, akan tetapi tidak dapat lepas dari peran manusia. Hubungan Tuhan dengan makhluknya baik berupa hubungan Tuhan dan manusia maupun Tuhan dan alam, menjadi sebuah kajian yang tidak statis akan tetapi dinamis dan berubah-ubah. Begitu juga dengan bagaimana Tuhan dan manusia, bagaimana batasan kemampuan dan usaha manusia, bagaimana kuasa manusia atas dirinya, dan bagaimana kekuasaan Tuhan yang absolut atas tindakan manusia itu.

Konsep pemahaman kajian teologi juga tidak terpisahkan dengan posisi agam dalam struktur sosial yang secara dialektis menimbulkan kesinggungan antara budaya dengan konstruksi sosial serta wacana teologi dalam setiap kelompok umat manusia. Perkembangan teologi sudah tidak terbatas hanya pada pembahasan mengenai ketuhanan secara eksklusif, akan tetapi sudah berkembang menjadi paduan dari banyak pemikiran keagamaan yang sudah memiliki interaksi dengan pemikiran kontemporer. Teologi Islam pada mulanya disibukkan hanya dengan membahas permasalahan yang sifatnya metafisika, sudah berkembangan menjadi suatu respon yang sifatnya positif serta kritis dalam menjawab berbagai permasalahan umat Islam.

Di Indonesia sendiri pemikiran Islam besifat sehingga ini menjadikannya menarik untuk dikaji. Hal ini ditunjukkan dari banyak buku yang ditulis untuk melihat perkembangan pemikiran di Indonesia, seperti halnya Kama Hasan (1982), Bachtiar Effendy (1998), Syafiii Anwar (1995), Fachry Ali (1987), Greg 
Barton (1995), M Rusli Karim (1998) dan Masykuri Abdillah (1999). Dari tulisan-tulisan mereka menunjukkan bahwa telaah atas pemikiran Islam di Indonesia semakin menemukan relevansi dan momentumnya. Meski demikian pemikiran Islam yang berkembang di Indonesia masih relatif sama, karena dasar pemikiran islam di Indonesia masih berkisar pada tema teologi, politik, dan negara yang di dalamnya memiliki kaitan dengan umat (masyarakat).

Dalam bukunya Zuly mengkaji diskursus pemikiran Islam liberal di Indonesia terkait hal berikut yakni wahyu Al-Qur'an, demokrasi, perjuangan umat, modernisasi, pluralisme agama, kesetaraan gender, syari'at islam, komunitas epistemic islam liberal, dan respon atas pemikiran liberal. Liberal muslim pria lainnya seperti Ali Shariati (wafat 1977) dan Fazlur Rahman (wafat 1988) mempresentasikan Islam dengan cara-cara yang membahas batasan yang ditempatkan pada perempuan dengan mengambil pendekatan kritis sejarah terhadap interpretasi tradisional. Secara khusus, Rahman menggunakan pendekatan sejarah kontekstualisasi dengan spesifik untuk mengkaji ayat-ayat tertentu dari Al-Quran yang kelihatannya untuk menjelaskan kekurangan terhadap perempuan, dalam urutan untuk menawarkan pembacaan yang lebih egaliter mempengaruhi kelompok para teologi wanita muslim sekarang.

Selanjutnya, Fazlur Rahman (1919-1988), dan sejumlah tokoh intelektual yang masih hidup sekarang, seperti Ashgar Ali Engiineer, Fatimah Mernissi, Amina Wadud Muhsin dan Riffat Hassan semuanya menyuarakan pentingnya rekontruksi pemikiran Islam tentang perempuan sehingga kelompok perempuan dapat menikmati hak-haknya sebagai manusia, seperti dijamin dalam Al-Quran. Pemikiran Muhammad Abduh dan Fazlur Rahman dalam bidang teologi mempunyai latar belakang yang sama, yaitu sebagai koreksi atas doktrin-doktrin yang telah mapan dalam berbagai aliran kalam. Bagi keduanya, konsep-konsep teologi yang dirumuskan mutakallimin terdahulu tidak selamanya menunjukkan gagasan yang setia pada ajaran-ajaran Al-Quran dan bahkan tidak sedikit yang terkena bias dari pemikiran asing. Sebagai alternatif, baik Abduh maupun Rahman menghendaki rumusan teologi 
yang sederhana sehingga tidak menimbulkan bentuk-bentuk pemahaman yang spekulatif.

Signifikansi metode studi Islam yang ditawarkan Fazlur Rahman untuk mengubah konsep bias gender menjadi sensitif gender, adalah tawarannya untuk memahami nash secara holistik, dan menghindari penggunaan metode atomistik. Khaled M. Abou el-Fadl dengan sangat brilian menjelaskan fenomena metodologis teologi penindasan yang dalam tesisinya disebut dengan sewenangwenang (the authoritarian) memulai teologi kesewenang-wenangan (penindasan) diawali kutipan sebuah ayat dari surah Al-Muddatssir dengan terjemahan "dan tidak seorang pun yang dapat mengetahui tentara-tentara Tuhan, kecuali Tuhan" dari segi teks, kemunculan teologi penindasan diaktualisasikan dalam klaim pembacaan teks otoritatif (misalnya ayat Al-Qura'an dan hadits) yang kemudian digunakan sebagai pijakan pemahaman satu-satunya yang perlu diikuti.

Persoalan yang sifatnya substansial dengan mengangkat sikap diskriminatif terhadap wanita adalah menjadi wujud adanya pemahaman akan agama yang beranggapan bahwa kekuasaan laki-laki atas wanita adalah keputusan dari Tuhan yang tidak dapat diubah baik dalam bahasa lain dan hirarki kekuasaan laki-lakilah yang diyakini. Formulasi bahasa yang sering dipakai seseorang yang mengunakan teologi penindasan ketika membaca sebuah ayat refleksi keimanannya adalah bahwa "firman Tuhan ini harus dihormati" sebagaimana firman Tuhan dihormati sebagaimana firman Tuhan tersebut dipahaminya. Hermeneutiknya yang menampilkan pendekatan holistik terhadap pesan Al-Quran diakui sebagai pengaruh rumusan oleh pendukung perintis keadilan gender AlQuran seperti bacaan baru yang dilakukan oleh Amina Wadud dan Asma Barlas.

\section{Aktivis Sosial dan Politik Wanita dan Gerakan Feminis}

Gerakan sosial Islam yang hadir sebagai bentuk respon dari berbagai kondisi sosial, politik, dan ekonomi yang dihadapi oleh umat Islam. Selama dekade-dekade awal abad kedua puluh, para wanita muslim memainkan peran penting publik baru dalam memperjuangkan kemerdekaan dan gerakan nasionalis dibagian dunia muslim. Sebagai contoh, pada tahun 1892-1920 tekanan wanita 
dan gerakan sosial wanita awal yang muncul di Mesir menggabungkan upaya amal dengan keinginan untuk mendidik massa dan memobilisasi mereka menuju kemandirian. Oleh karena itu, Hermansen mengatakan bahwa telah menemukan bukti baru untuk keterlibatan wanita muslim sebagai aktivis dan sarjana-sarjana dalam berbagai gerakan perempuan yang muncul pada masyarakat muslim di awal abad ke 20, serta dalam dokumen-dokumen yang di hasilkan oleh kelompokkelompok ini. Pada akhirnya, wanita muslim, seperti rekan-rekan feminis barat mereka berupaya mencapai atau meningkatkan hak-hak perempuan melalui rekonstruksi teoritis, serta melakukan inisiatif praktis.

Di Barat yang pada kenyataannya, secara global dan dalam ruang lingkup dan teori feminis telah berkembang dari "gelombang pertama" atau keprihatian feminis awal seperti menuntut hak pilih dan hak-hak dasar perempuan, "gelombang kedua" kritik teoritis patriarki yang tertanam, tidak hanya dalam institusi sosial, tetapi juga dalam urutan dan krontuksi dari kategori pengetahuan. Perempuan kulit berwarna lebih lanjut mengkritik sifat putih dan istimewa agenda feminis sebelumnya menghasilkan "budaya" atau "gelombang ketiga" feminism yang menyadari perbedaan keprihatinan khusus dari bukanBarat, perempuan bukan-istimewa.

Pada tahun 1960-an, saat gerakan-gerakan liberal muncul dan terutama setelah beety Friedan menerbitkan buku berjudul The Feminine Mystique (1963), gerakan feminism menuai zamannya. Di mana gerakan feminime menjadi suatu kejutan besar bagi masyarakat karena mampu memberikan kesadaran baru, khususnya bagi kaum wanita terhadap peran wanita mengenai pandangan tradisional yang menempatkan wanita pada posisi yang tidak menguntungkan yakni peran subordinasi.

Rekontruksi pemikiran Islam tentang perempuan diberbagai negara Islam membawa kepada lahirnya hukum keluarga baru yang semakin mengakomodasikan hak-hak perempuan. Sejarah Islam mencatat usaha-usaha pembaharuan hukum keluarga mulai merebak sejak awal abad ke-20. Di mulai dari Turki yang pada 1917 melakukan pembaharuan hukum perkawinan dengan membuat Qanun Qarar al-Huquq, al- 'A ' ilah al- 'Usmaniyyah atau Ottoman Law 
of Family Rights. Isu yang menonjol dalam hukum keluarga Turki itu adalah larangan poligami secara mutlak. Teologi pada wanita muslim tidak hanya terjadi pada konteks penafsiran Al-Quran dan hadis saja, tetapi terjadi juga pada gerakan-gerakan aktivis islam, politik islam dan gerakan feminis hingga melahirkan pemikiran-pemikiran yang bebas dari budaya-budaya maupun adat yang patriarki maupun misoginis kepada wanita.

Dalam jurnalnya Asfa Afifah menyatakan bahwa Qasim Amin merupakan tokoh feminis muslim pertama yang dilahirkan di Tarah, Iskandariah (Mesir) pada Desember 1865. Gagasan Qasim Amin tentang emansipasi menyulut kontroversi diskursus di kalangan ulama Mesir pada waktu itu. Ide emansipasi yang dibangunnya bertujuan untuk membebaskan kaum perempuan sehingga mereka memiliki kekuasaan dalam berpikir, berkendak, dan beraktivitas sebatas yang dibenarkan oleh ajaran Islam dan mampu memelihara standar moral masyarakat.

\section{Feminis Islam dan Wanita Muslim Sebagai Teolog}

Seiring dengan berkembangnya gerakan-gerakan Islam dan moderasi keanggotaan feminisasi, peran perempuan dalam aktivisme gender sangat perlu diperhitungkan. Secara peningkatannya, perempuan islamis atau perempuan muslim yang "saleh" diidentifikasi memiliki peran penting dalam beberapa kasus penulis dan ahli teori isu gender. Dalam hal ini yang menonjol adalah tokoh-tokoh seperti Zaynab al-Ghazali dan Bint al-Shati dalam kelompok-kelompok sebelumnya. Dalam beberapa gerakannya al-Ghazali memberikan bantuan berupa dorongan untuk para aktivis muslim pria maupun wanita yang muncul pada tahun 1980an. Orang-orang inilah yang berusaha mengubah para wanita mendapatkan kebebasan dan berpendidikan. Perubahan ini sangat terlihat khususnya pada kalangan mahasiswa, di mana cara berpakaian mereka dari rok mini dan pakaian adat yang diimpor ke Barat untuk merangkul kesalehan yang bersifat personal dan untuk mencari keaslian Islam.

Dalam bukunya yang berjudul Muslima Thelogy, Marcia Hermansen mengutip ilmuwan Mesir yakni Heba Raouf Ez-zat sebagai salah satu perwakilan feminis intelektual Islam. Seperti gerakan al-Huda yang ada di Pakistan dan 
Kanada, di mana gerakan ini digerakkan oleh cendekiawan Islam yang bercirikan Niqab, menyelenggarakan kursus-kursus yang memungkinkan para wanita muslim untuk memperoleh pengetahuan dasar mengenai studi Al-Qur'an dan hadits.

Dalam hal ini beberapa teolog muslim wanita seperti Amina Wadud dan Asma Barlas yang mengutip karya pemikir liberal muslim yakni Fazlur Rahman dan menjadikannya inspirasi karena Fazlur memprakarsai hermeneutika membaca Al-Qur'an secara holistik dalam rangka untuk menentukan semangat dibalik kekuatan liberal suatu pemerintahan. Pemikiran Fazlur Rahman ini mejadi rujukan bagi Amina Wadud, di mana Amina Wadud berpijak pada pemahaman bahwa penafsiran memiliki nilai yang relatif, sehingga pemikiran Amina Wadud ini memumculkan satu rumusan baru yang dapat membedakan antara agama dan pemikiran agama.

Secara eskplisit metodologi yang digunakan pada teologi muslim wanita adalah pendekatan hermeneutis feminis. Pendekatan hermeneutis feminis tersebut digunakan untuk menganalisis artikulasi tradisional yang dominan mengenai makna teks yang "benar". Pendekatan ini diprakarsai oleh Amina Wadud, kemudian Wadud mengembangkannya menjadi hermeneutika Al-Qur'an dari sudut pandang gender yang disebut dengan hermeneutika feminis. Dalam penerapan metodologi ini yakni dengan meletakkan dasar kecurigaan hermeneutik atau interpretasi makna yang dicurigai dapat menimbulkan bias hirarkis dan patriarkal yang ditanggung dalam merumuskan interpretasi makna sebelumnya.

Selain Amina Wadud, terdapat Asma Barlas menjelaskan dalam bukunya Believing Woman in Islam bahwa terdapat tiga poin utama yang mendominasi patriarki dalam menafsirkan teks-teks agama mengenai seksualitas dan gender, dalam hal ini adalah pernikahan dan keluarga. Dengan melakukan hal tersebut, ia mendesak orang untuk menafsirkan Al-Qur'an secara bebas dengan tujuan untuk membebaskan penafsiran dan prasangka patriarki. Selain itu, Barlas juga menjelaskan secara luas mengenai pembebasan dan sistem egaliter dalam AlQur'an. Hal ini mendorongan para perempuan untuk turut berperan dalam menafsirkan islam sebagai sumber daya untuk mendapatkan ide-ide yang 
seimbang mengenai isu gender. Demikian ini dilakukan Barlas karena sejauh ini para pria yang mendominasi wilayah tersebut (penafsiran) sehingga suara wanita tidak terlihat signifikan.

Tidak seluruhnya intervensi teologis yang ada saat ini yang muncul dari para muslim wanita disampaikan oleh kesadaran akan studi gender dan konteks studi yang cukup luas mengenai wanita dalam agama. Wacana konservatif akan wanita dalam agama atau sebaiknya ini secara khusus dalam Islam, acap kali menghadirkan konsep penting tentang "wanita muslimah" dan mereka mungkin merupakan "wanita" abstrak namun ideal dari ideologi agama dan fantasi dari sebuah kesalehan. Singkatnya, ruang lingkup wanita Muslim dalam menulis teologi jauh dari kata jelas dan bersifat kokoh. Hal ini dapat disimpulkan bahwa bidang teologi "Muslima" masih sangat berkembang dalam diskusi dengan aktivisme global akan hak-hak perempuan Muslim.

Selaras dengan penjelasan di atas Marcea Hermansen menggambarkan contoh lain dari penelitian yang dilakukan Saba Mahmood pada wanita saleh dari gerakan masjid wanita di Mesir, di mana gerakan masjid wanita ini mampu merebut kembali ruang keagamaan publik sebagai bagian dari mengejar pengetahuan Islam dan merangkul gaya hidup religius secara pribadi. Mahmood sendiri menggunakan konsep sosiologi Bourdieu untuk mengeksplorasi pertumbuhan dan implikasi dari Habitus Muslim untuk kesalehan wanita di Mesir modern. Dengan menggunakan argumen yang kritis, Mahmood mengemukakan bahwa wanita tersebut dengan menguasai wacana teks islam klasik dan mengadopsi kebiasaan perilaku saleh, dapat membantu wanita untuk mengekespresikan hak pilihan dan hak otonomi mereka dengan tujuan membentuk feminisme dalam kerangka islam. Sehingga kerja feminis islam berdasarkan pada sumber-sumber utama ajaran Islam, yakni Al-Qur'an, Hadis, dan seperangkat hukum Islam.

Fenomena di atas menunjukkan bahwa teologi wanita awal mula rekonstruksi yang dibangung didominasi oleh letupan-letupan gender yang muncul dari kesadaran partisipasi wanita dalam ruang publik dan kesadaran feminis. Di mana kesadaran tersebut berupa gugatan-gugatan praktis, akan tetapi 
belum menyentuh aspek teologisnya sendiri. Sehingga ini memuncul tantangan epistimologis berupa pengembangan gugatan-gugatan yang akan menjadikan gugatan-gugatan gender tersebut hilang dan sekedar asumsi semata.

\section{SIMPULAN}

Gerakan kesalehan modern tampaknya memiliki daya tarik tersendiri yang kuat bagi wanita. Pada nyatanya, perempuan selama ini hanya dijadikan objek "eksploitasi" dari aspek kesehatan, ekonomi, politik, biologis, psikologis, keagamaan, dan sebagainya. Aspek yang paling mudah adalah "mengagungkan" perempuan melalui legitimasi pemahaman atas teks-teks suci agama yang bias gender. Islam sendiri menaruh perhatian yang besar terhadap persoalan-persoalan perempuan. Buktinya di dalam Al-Qur'an persoalan-persoalan perempuan dibicarakan diberbagai surat dan ayatnya. Pembicaraan tersebut menyangkut berbagai sisi kehidupan perempuan. Ada surat dan ayat Al-Quran yang berbicara tentang asal kejadian perempuan, hak dan kewajiban perempuan, dan keistimewaan tokoh-tokoh perempuan dalam sejarah agama atau kemanusiaan.

Pada nyatanya, rekonstruksi teologi wanita sampai saat ini masih didominasi oleh letupan-letupan gender, akan tetapi belum menyuntuh pada aspek teologinya sendiri. Maka dari itu, teologi wanita menghadapi tantangan epistimologis yakni mengembangkan gugatan-gugatan yang sudah ada, supaya tidak hanya menjadi asumsi dari teologi wanita. Selain itu, hal ini juga menunjukkan bahwa kedudukan wanita sebagai teolog muslim wanita masih dalam perdebat, karena karya para teolog muslim wanita yang sudah ada masih jauh dari kata jelas dan bersifat kokoh. 


\section{DAFTAR PUSTAKA}

Al Makin. Keragaman dan Perbedaan. Yogyakarta: Suka Press, 2016.

Aslan, Ednan, dan Marcia Hermansen. Muslima Theology: The Voices of Muslim Women Theologians. Frankfrut: Peter Lang, 2013.

Azir, Ahmad Amir. Pembaharuan Teologi: Perspektif Modernisme Muhammad Abduh dan Neo-Modernisme Fazlur Rahman. Yogyakarta: Teras, 2009.

Dewi, Ernita. "Pemikiran Amina Wadud Tentang Rekonstruksi Penafsiran Berbasis Metode Hermeneutika." Jurnal Substansial 15, no. 2 (Oktober 2013): 145-67.

Esa, Muhammad In'am. Retinking Kalam Sejarah Sosial Pengetahuan Islam. Yogyakarta: eLsAQ, 2006.

Fikriah, Asfa, dan Lalu Iwan Eko Jakandar. "Perkembangan Pemikiran dan Pergerakan Wanita Dalam Pandangan Feminis Muslim.” Jurnal Sosial, Politik, Kajian Islam dan Tafsir 1, no. 2 (Desember 2018): 188-209.

Jurdi, Syaifudin. "Gerakana Sosial Islam: Kemunculan, Eskalasi, Pembentukan lok Politik,dan Tipologi Artikulasi Gerakan." Jurnal Politik Profetik 1, no. 1 (2013): 1-24.

Khatibah. "Penelitian Kepustakaan.” Jurnal Iqra' 05, no. 01 (Mei 2011): 36-39.

Mulia, Siti Musdah. Islam dan Hak Asasi Manusia. Jakarta: Naufan Pustaka, 2010.

Islam dan Hak Asasi Manusia. Jakarta: Naufan Pustaka, 2010.

Muqoyyidin, Andik Wahyun. "Wacana Kesetaraan Gender: Pemikiran Islam Kontemporer Tentang Gerakan Feminisme Islam.” Jurnal Al-Ulum 13, no. 2 (2013): 491-512.

Nasution, Khoiruddin. Fazlur Rahman Tentang Wanita. Yogyakarta: Tazzafa \& Academia, 2002.

Qodir, Zuly. Islam Liberal: Varian-Varian Liberalisme Islam di Indonesia 19912002. Yogyakarta: Lkis Pelangi Aksara, 2010.

Reese, William L. Dictionary of Philosophy and Religion Eastern and Western 
Thought. USA: Humanities Press Ltd., 1980.

Rinakit, Sukardi. Nalar Kemanusiaan Nalar Perubahan Sosial. Jakarta: PT Mizan Publika, 2006.

Suparwany. "Women Interpretation on Qur'an Islamic Institution and Communities.” Jurnal At-Tibyan 2, no. 2 (2017): 208-22.

Syafi'i, Ma'arif. Islam Kekuatan Doktrin dan Keagamaan Umat. Yogyakarta: Pustaka Pelajar, 1997.

Turner, Bryan S. Debating Islam, Secularism, Democracy and Muslim Polity Islam, Public Religious and the Secularization Debate dalam Muslim Societies and the Challenge of Secularization an Interdiscplinary Approach. USA: Cambridge University Press, 2011.

Zed, Mestika. Metode Penelitian Kepustakaan. Jakarta: Yayasan Pustaka Obor Indonesia, 2004. 
